\title{
The Roles of Autophagy in Cancer
}

\author{
Chul Won Yun ${ }^{1}$ and Sang Hun Lee ${ }^{1,2, *(1)}$ \\ 1 Medical Science Research Institute, Soonchunhyang University Seoul Hospital, Seoul 04401, Korea; \\ skydbs113@naver.com \\ 2 Department of Biochemistry, Soonchunhyang University College of Medicine, Cheonan 31538, Korea \\ * Correspondence: ykckss1114@nate.com; Tel.: +82-02-709-2029
}

Received: 15 October 2018; Accepted: 2 November 2018; Published: 5 November 2018

\begin{abstract}
Autophagy is an intracellular degradative process that occurs under several stressful conditions, including organelle damage, the presence of abnormal proteins, and nutrient deprivation. The mechanism of autophagy initiates the formation of autophagosomes that capture degraded components and then fuse with lysosomes to recycle these components. The modulation of autophagy plays dual roles in tumor suppression and promotion in many cancers. In addition, autophagy regulates the properties of cancer stem-cells by contributing to the maintenance of stemness, the induction of recurrence, and the development of resistance to anticancer reagents. Although some autophagy modulators, such as rapamycin and chloroquine, are used to regulate autophagy in anticancer therapy, since this process also plays roles in both tumor suppression and promotion, the precise mechanism of autophagy in cancer requires further study. In this review, we will summarize the mechanism of autophagy under stressful conditions and its roles in tumor suppression and promotion in cancer and in cancer stem-cells. Furthermore, we discuss how autophagy is a promising potential therapeutic target in cancer treatment.
\end{abstract}

Keywords: autophagy; cancer; cancer stem-cells; autophagy modulators

\section{Introduction}

Autophagy is a physiological cellular process for the degradation and elimination of misfolded proteins and damaged organelles that functions in adaptation to starvation, development, cell death, and tumor suppression [1,2]. One of the important mechanisms of autophagy is an intracellular degradation pathway mediated by double membrane vesicles called autophagosomes. These autophagosomes deliver degraded cytoplasmic components to the lysosome to be recycled during stressful conditions. This mechanism of autophagy is essential for protecting cells from damaged proteins, to shield cell organelles from toxins, to maintain cell metabolism and energy homeostasis, and to promote cell survival (Figure 1).

Autophagy can be general (non-selective) or selective. General autophagy packages portions of the cytoplasm into autophagosomes and delivers them to lysosomes for degradation. In contrast, selective autophagy works by recognizing specific targets, such as damaged cell organelles, protein aggregates, and intracellular pathogens. Recently, it has been reported that defects of autophagy are associated with genomic damage, metabolic stress, and tumorigenesis [3]. In addition, many studies suggest that autophagy has been linked to both cancer initiation and cancer therapy for several years $[4,5]$. Indeed, some studies suggest that autophagy is a regulator of many oncogenes and tumor suppressor genes [6,7], whereas other studies have shown that autophagy is involved in both the promotion of tumorigenesis and the development and inhibition of cancer [8-11].

In this review, we summarize the typical biological mechanism of autophagy, as well as the role of autophagy in cancer, such as in tumor suppression and promotion, cancer-drug resistance, 
and metastasis. Next, we discuss the interaction between autophagy and cancer stem-cells. Finally, we discuss autophagy as a therapeutic target in cancer treatment.

\section{Overview of Autophagy}

Autophagy is an evolutionarily conserved intracellular recycling system and cellular self-degradation process that maintains metabolism and homeostasis. Autophagy responds to a range of cellular stresses, including nutrient deprivation, organelle damage, and abnormal protein accumulation (Figure 1) [12,13]. This autophagic process can be associated with cell death and cell survival [14-16]. During nutrient deprivation, autophagy is enhanced to maintain a provision of important proteins and other nutrients to serve as an energy supply, thereby increasing cell survival [17]. Recent studies reported that hypoxia can regulate autophagy, inducing processes that alleviate the oxidative stress caused by low levels of oxygen $[18,19]$.

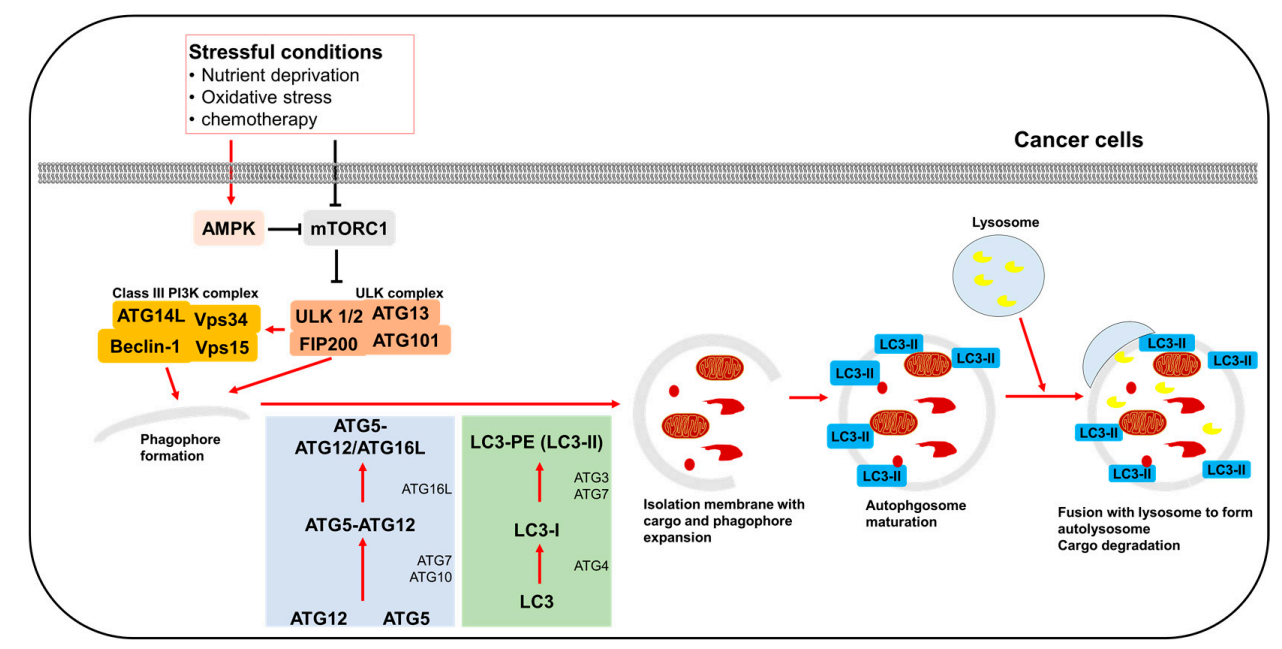

Figure 1. A schema illustrating the regulation of the autophagic pathway under diverse stressful conditions in cancer cells.

Under normal conditions, cells utilize basal levels of autophagy to aid in the maintenance of biological function, homeostasis, quality-control of cell contents, and elimination of old proteins and damaged organelles $[1,20]$. Additionally, autophagy in stem cells is related to the maintenance of their unique properties, including differentiation and self-renewal [21,22]. In cancer cells, autophagy suppresses tumorigenesis by inhibiting cancer-cell survival and inducing cell death, but it also facilitates tumorigenesis by promoting cancer-cell proliferation and tumor growth [8,9].

The mechanism of the autophagic process is controlled by a series of proteins. Mammalian target of rapamycin (mTOR) is associated with cell proliferation, stress, and cancer progression. mTOR consists of two complexes, mTORC1 and mTORC2, each of which exhibits distinct functions and localization [23-25]. Activated mTORC1 plays a pivotal role in the phosphorylation of autophagy-related protein (ATG) and leads to the inhibition of autophagy. When mTORC1 is inhibited under various stressful conditions, such as starvation and organelle damage, autophagy is enhanced. mTORC1 is regulated by AMP-activated protein kinase (AMPK), and inhibition of MTORC1 and increased AMPK induces the autophagic process $[26,27]$. However, the role of mTORC1 in autophagy is not clear [28].

When mTORC1 is inhibited, the Unc-51-like autophagy-activating kinase (ULK) complex is dephosphorylated so it becomes activated [29]. The activated ULK complex localizes to the phagophore and activates the class III PI3K [30]. Beclin-1 recruits many proteins involved in maturation and elongation of the autophagosome [31]. Elongation of autophagosome formation is regulated by ATGs. ATG5-ATG12/ATG16L complexes recruit microtubule-associated protein 1 light chain 3 (LC3) and are associated with expansion of the phagophore [32,33]. Next, LC3 drives phagophore elongation. Pro LC3 is converted to the active cytosolic isoform LC3 I by ATG4B. Next, LC3 I is converted to 
LC3 II by interacting with phosphatidylethanolamine (PE), ATG3, and ATG7. LC3 II is located in the inner and outer membrane of the autophagosome, enabling it to bind to degraded substrates [34-36]. Mature autophagosomes can fuse with lysosomes to form autolysosomes, which selectively remove proteins and damaged organelles via autophagy [37].

\section{The Role of Autophagy in Cancer}

Autophagy plays major roles in the degradation of damaged organelles and old proteins and in the maintenance of cellular homeostasis [38-40]. In cancer biology, autophagy plays dual roles in tumor promotion and suppression and contributes to cancer-cell development and proliferation $[8,9]$. Some anticancer drugs can regulate autophagy. Therefore, autophagy-regulated chemotherapy can be involved in cancer-cell survival or death $[10,11]$. Additionally, the regulation of autophagy contributes to the expression of tumor suppressor proteins or oncogenes. Tumor suppressor factors are negatively regulated by mTOR and AMPK, resulting in the induction of autophagy and suppression of the cancer initiation [41]. In contrast, oncogenes may be activated by mTOR, class I PI3K, and AKT, resulting in the suppression of autophagy and enhancement of cancer formation [42].

Reduced and abnormal autophagy inhibits degradation of damaged components or proteins in oxidative-stressed cells, leading to the development of cancer. In addition, basal autophagy is considered a factor of cancer suppression $[43,44]$. The mutation of important autophagy proteins suppresses development of tumors. BIF-1 proteins that are related to BECN1 have been observed to become abnormal or absent in variety of cancer types, such as colorectal and gastric cancer [45-47]. UVRAG proteins are also related to BECN1 and function as autophagy regulators. The mutation of UVRAG reduces autophagy, resulting in increased cancer-cell proliferation in colorectal cancer cells [48]. On the other hand, a high basal-level of autophagy is observed in several types of RAS-activated cancer, such as pancreatic cancers [49]. Inhibition of increased autophagy in these cancers decreases cell proliferation and promotes tumor suppression [50]. Therefore, autophagy plays roles in tumor initiation and suppression, and we discuss the diverse roles of autophagy as an inducer of oncogenesis and as a tumor suppressor in following sections (Figure 2).

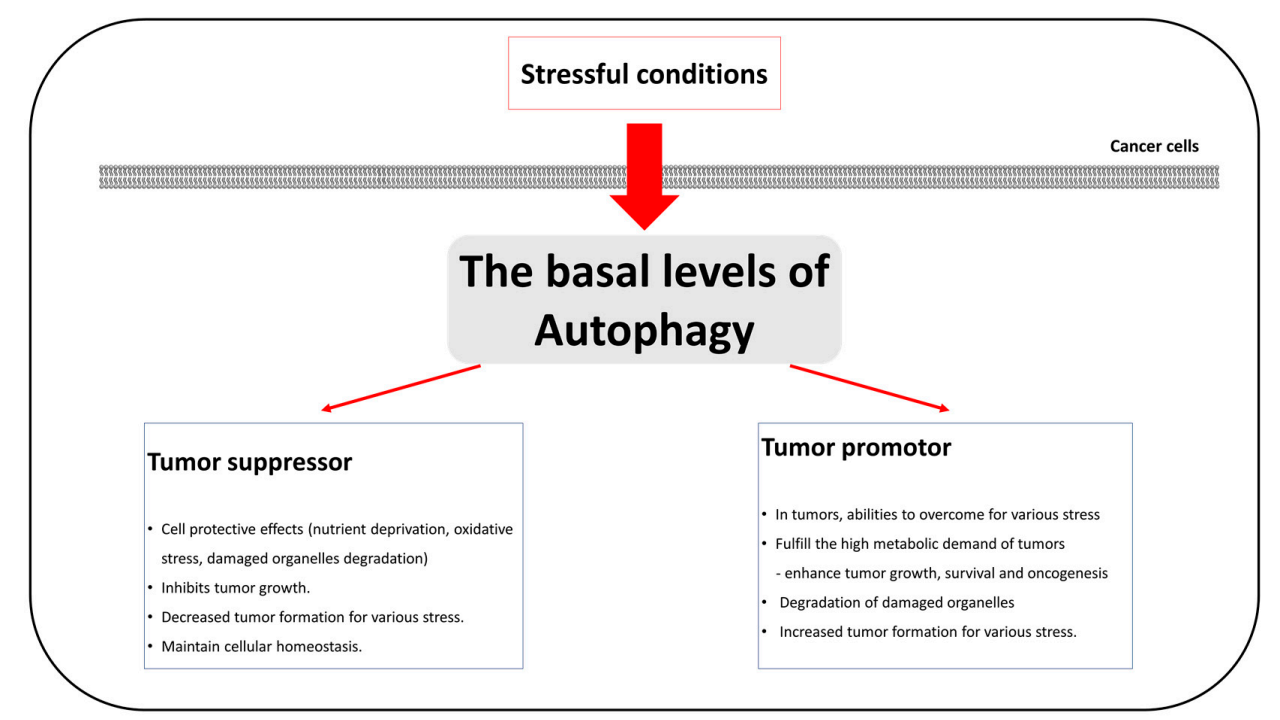

Figure 2. A schematic diagram of the autophagy roles of tumor promotor and suppressor in cancer cells.

\section{Autophagy as a Regulator of Tumor Suppression}

The basal level of autophagy operates as a mechanism for tumor suppression via reduction of damaged cellular parts and proteins and maintenance of cellular homeostasis [51]. Previous studies have reported that the depletion of the autophagy-related gene BECN1 (encoded for Beclin 1) is observed in a variety of human breast, prostate, and ovarian cancers [44,52,53]. Beclin 1 is important 
in the formation of the phagophore, suggesting that Beclin 1 functions as a tumor suppressor. In cancer-cell lines and mice models, the loss of BECN1 results in a reduction of autophagy and an increase in cell proliferation, further indicating that BECN1 gene acts as a tumor suppressor $[44,53,54]$. In addition, several studies have shown that the level of Beclin 1 is decreased in various cancers, such as cervical squamous-cell carcinomas and hepatocellular carcinomas [55-58]. Other studies have reported that the depletion of other key autophagy genes suppresses tumor progression in cancer. A variety of proteins, including UV radiation resistance-associated gene (UVRAG) and Bax interacting factor-1 (Bif-1), which associate with BECN1 function as tumor suppressors and positively regulate autophagy [59]. The depletion of UVRAG and decrease of Bif-1 impaired autophagosome formation and autophagy, resulting in increased cancer-cell proliferation in colon, gastric, breast, and prostate cancers $[45,48,60,61]$.

In mice with knockout of autophagic core proteins, deletion of ATG5 and ATG7 generates liver cancers from autophagy-deficient hepatocytes due to damaged mitochondria and oxidative stress [62]. Other studies have shown that the deficiency of autophagic regulators, such as ATG3, ATG5, ATG9, is associated with oncogenesis [63-66]. Mice deficient in ATG4 have been observed to have increased susceptibility to the generation of fibrosarcomas when exposed to chemical carcinogens [67]. In addition, autophagy prevents tumor generation through the regulation of reactive oxygen species (ROS). Damage to mitochondria induces excessive ROS production, resulting in promotion of carcinogenesis [68-70]. These results suggest that autophagy is a crucial mechanism that inhibits tumor generation, and impaired autophagy may result in oncogenesis.

\section{Autophagy as a Regulators of Tumor Promotion}

Several studies indicate that autophagy acts to promote tumor survival and growth in advanced cancers [71,72]. Tumors are exposed to extremely stressful conditions, including hypoxia and nutrient deprivation. Autophagy helps cells to overcome these stresses. Autophagy is activated in the central part of solid tumors, where cells exist under hypoxic conditions. Suppression of autophagy by deletion of Beclin 1 enhances cell death [73,74]. In addition, autophagy fulfills the high metabolic and energetic demands of proliferating tumors by recycling intracellular components to supply metabolic substrates [75,76]. In animal studies, metabolic stress is observed in autophagy-deficient cells, resulting in impaired cell survival [77]. Therefore, autophagy contributes to tumor-cell survival by enhancing stress tolerance and supplying nutrients to meet the metabolic demands of tumors, and the inhibition of autophagy or knockdown of autophagy genes can result in tumor-cell death [5,78].

Autophagy is also increased in RAS-mutated cancer cells that maintain a high basal-level of autophagy. RAS are small GTPases involved in important signal pathways for proliferation, survival, and metabolism [79-81]. RAS-activating mutation increases autophagy, which enhances tumor growth, survival, and oncogenesis, and is associated with the development of some deadly cancers, including lung, colon, and pancreatic [82-85]. Some studies have revealed that a high level of autophagy is observed in RAS-activating mutated cells, and cell survival is dependent on autophagy during nutrient starvation [86,87]. In addition, inhibition of autophagy-related protein enhances the accumulation of damaged mitochondria and decreases cell growth [88-90]. These results indicate that autophagy plays an important role in cell survival of several tumors that depend on RAS activation.

\section{Interaction between Autophagy and Cancer Microenvironment}

Many studies have shown that the cancer microenvironment is affected by autophagy in cancer cells. The cancer microenvironment consists of several factors including hypoxia, inflammation, and cytokines [91]. Autophagy supplies the demand for cellular energy and prevents cytotoxicity under stressful conditions in cancer microenvironments [92,93].

Previous studies suggested that many cancers exhibit hypoxic conditions as one of the cancer microenvironmental factors [92]. Hypoxic conditions in cancer may affect the autophagy pathway to enable cancer cells to adapt and survive under low oxygen conditions via the stress response 
signaling pathway, such as hypoxia-inducible factor- 1 alpha (HIF- $1 \alpha)$. Under hypoxia conditions, HIF- $1 \alpha$ induces activation of autophagy in cancer progression [94] and regulates many of its target genes [95]. HIF- $1 \alpha$ is also indirectly regulated by the autophagic process via changes in glucose metabolism. These processes promote glucose metabolism by HIF- $1 \alpha$, and a series of processes enhance autophagy $[95,96]$. HIF- $1 \alpha$-independent autophagy is associated with glucose and amino acid deprivation and activated by the induction of AMPK and inhibition of mTOR [94].

Inflammatory regulators are highly induced in the cancer microenvironment, indicating that inflammation contributes to tumorigenesis [97]. Some studies showed that inflammation triggers high levels of reactive oxygen species (ROS) in cancer cells, macrophages, and other immune cells, which secrete chemokines and cytokines, including interleukin- 6 , tumor necrosis factor- $\alpha$, interleukin-10, and transforming growth factor- $\beta$ into the cancer microenvironment [91]. These cytokines play crucial roles in inducing chronic inflammation and have anticancer effects as well as contribute to cancer progression via inflammation [98]. Inflammation is also induced by autophagy in the cancer microenvironment and cancer adjacent cells, resulting in cancer progression. Moreover, other studies demonstrated that inflammation is one factor involved in tumorigenesis and reduces autophagy activation [99]. Additionally, autophagy suppresses inflammation by inhibiting NLRP3 formation and autophagy-related protein, and ATG16L was found to modulate intestinal homeostasis and inflammation [65].

\section{Autophagy as a Regulator of Cancer Metastasis}

Cancer cells possess the ability to engage in metastasis, which is the invasion and colonization of new tissues and organs via the vascular and lymphatic systems. During metastasis, cancer cells in the origin site experience increased motility to migrate to secondary sites. In primary cancer cells, autophagy is induced by hypoxia and nutrient deprivation and protects against cell necrosis and inflammation [100-102]. Autophagy has demonstrated both pro-metastatic and anti-metastatic effects [100]. Autophagy acts in an anti-metastatic role via limitation of cancer necrosis and inflammation responses in early stages of cancer metastasis. In early metastasis, autophagy also reduces invasion and migration of cancer cells from origin sites. However, in advanced stages of metastasis, autophagy acts in a pro-metastatic role via promotion of cancer-cell survival and colonization in secondary sites.

Autophagy is anti-metastatic. The knockdown of autophagy-related genes, such as Beclin 1 and LC3, is inhibited proliferation, migration, and invasion, which lead to apoptosis in breast cancer [103]. A decrease in ATG5 expression, a key regulator of autophagy, reduced survival rate in 158 primary melanoma patients, and decreased ATG5 expression promotes cancer-cell proliferation and is associated with the progression of early stage cancer [104]. One study shows that blocking mTOR signaling induces autophagic cell-death and inhibits metastasis in gastric cancer cells [105].

Autophagy is also pro-metastatic. In order to undergo metastasis, cancer cells must be able to survive and proliferate in the absence of ECM, and circulation systems and dissemination to secondary sites are essential as well [106]. Cancer cell death is induced by apoptosis following the loss of ECM attachment, called anoikis. Substantial evidence indicates that autophagy enables ECM-detached cancer cells to avoid anoikis and survive [107]. One study has shown that the inhibition of autophagy reduces metastasis of hepatocellular carcinoma (HCC) in a lung metastasis model, and the inhibition of autophagy is not only reduced invasion and migration but also reduced anoikis resistance and lung metastasis of HCC cells [108]. Another study indicates that autophagy induces ECM detachment and the inhibition of $\beta 1$ integrin [109].

Epithelial mesenchymal transition (EMT) is a major biological process that changes the epithelial phenotype to the mesenchymal phenotype [110]. These processes induce metastasis of cancer, leading to a lack of cell-cell adhesion, cell polarity to increase of cell motility, polarity, and invasiveness [111,112]. Additionally, EMT is important in embryonic development and affects wound healing and cancer progression. Some studies suggested that autophagy is associated with EMT in cancer. EMT-activated cancer cells have a high level of autophagy to survive under several stressful conditions during 
the metastatic process in cancer [113-115]. One study indicated that induction of autophagy by nutrient deprivation and mTOR inhibition reduced cell migration and invasion in glioblastoma cells [116]. Additionally, knockdown of autophagy-related proteins, such as Beclin 1, ATG5, and ATG7, increased the migration and invasion with EMT regulators in glioblastoma cells. Another study demonstrated that cadherin-6, a type 2 cadherin that induces EMT in embryonic development, is abnormally enhanced in cancer and associated with cancer progression [117].

\section{Autophagy as Drug-Resistant Factor of Tumors}

Several studies have revealed that the resistance of cancer cells to a variety of anticancer drugs can increase via upregulation of autophagy $[118,119]$. Autophagy is a protective mechanism in cancer cells undergoing anticancer therapy. Cancer chemotherapy with anticancer drugs damages dividing cells and interrupts cancer-cell division. Chemotherapy is a common treatment strategy for cancer therapy, but the success rate of chemotherapy is often limited because of the development of chemoresistance. In particular, induction of protective autophagy is a major challenge in cancer therapy. 5-Fluorouracil (5FU) is one anticancer drug used in solid cancers, such as breast, pancreatic, and colorectal cancer [120]. 5FU inhibits thymidylate synthetase and then leads to the inhibition of DNA synthesis [121]. However, the efficacy of treatment with 5FU is restricted, because protective autophagy is induced, resulting in chemoresistance in various cancer cells. The mechanism of protective autophagy is induced by beclin-1 expression, followed by conversion of LC3I to LC3II. Then, JNK-mediated protective autophagy and an increase of BCL2 increases autophagic flux and induces chemoresistance [121-123].

In addition, cisplatin is a primary treatment drug in many solid cancers, and its anticancer effects are induced by the generation of DNA damage and mitochondrial apoptosis [124]. However, the efficacy of treatment with cisplatin is restricted by the development of chemoresistance [125]. As the mechanism of cisplatin-mediated resistance, autophagy contributed to drug resistance in ovarian cancer via the modulation of ERK pathway and overexpression of Beclin $1[126,127]$. Another study has shown that cisplatin treatment promotes protective autophagy via the upregulation of Beclin 1, conversion of LC3 proteins, and increase of ATG7 expression in esophageal cancer [128,129]. Furthermore, cisplatin treatment combined with the inhibition of autophagy significantly increased cytotoxicity in esophageal cancer [130]. Chemoresistance to various chemotherapeutic agents is induced by protective autophagy in many cancers. Therefore, the efficacy of chemotherapeutic agents in many cancers is restricted by the induction of unexpected protective autophagy, and chemoresistance could be overcome via investigation of the autophagy pathway and the proper regulation of autophagy levels.

Autophagy contributes to the application of immunity in anticancer therapy. Immune effects in anticancer therapy occur through several steps. Cancer neoantigen is released into the surrounding environment and presented to $\mathrm{T}$ cells, and then cancer cells are killed through $\mathrm{T}$ cell-mediated cytotoxicity [131]. Other immune related cells are also induced and eliminate cancer cells presenting neoantigen through the generation of interferon- $\gamma$ and perforin. Autophagy is associated with the survival and death mechanisms in many cell types. Inhibition of autophagy-related proteins, including Beclin 1 and ATG7, impairs the survival of T cells by damaging ER homeostasis, causing mitochondrial dysfunction, and increasing ROS [132,133]. Autophagy is associated with T-cell survival. However, hypoxia-mediated autophagy leads to resistance of T-cell cytotoxicity via activation of STAT3. One study showed that the inhibition of autophagy by silencing of Beclin 1 and ATG5 decreased hypoxia-induced activation of STAT3 and restored cancer cell sensitivity to T-cell cytotoxicity [134]. Therefore, abnormal activation of STAT3 reduced the sensitivity of the immune response.

\section{The Role of Autophagy in Cancer Stem-Cells}

Cancer stem-cells (CSC) are a small subpopulation of cancer cells that have the abilities of self-renewal and differentiation and contribute to tumor initiation, chemoresistance, and metastasis $[135,136]$. Several studies have investigated the mechanism underlying maintenance of stemness maintenance in 
these cells, and autophagy may play an important role in this process $[137,138]$. A previous study has shown that autophagy regulates homeostasis of CSCs [139].

In glioma stem cells, the inhibition of autophagy suppresses differentiation, whereas enhancement of autophagy promotes differentiation [140]. A study has revealed that the decrease of LC3B-II and Beclin-1 are related to the development of astrocytic tumors [58]. However, one study indicates that autophagic cell death is observed in glioma stem cells. The suppression of autophagy by cilengitide, an integrin antagonist, attenuates cytotoxicity [141]. Thus, it is unclear whether autophagy regulates stemness in glioma stem cells.

In breast cancer stem-cells, a previous study has shown that CSCs contribute to the recurrence of cancer and metastasis [142]. Autophagy is observed to positively modulate mesenchymal-like phenotypes in breast cancer stem-cells. Silencing of two autophagy-related proteins, LC3B and ATG12, or treatment with autophagy inhibitors directly reduces cancer stem-cell-like phenotypes [143]. Several studies demonstrate that autophagy is associated with protective effects against various cellular stresses in breast CSCs $[144,145]$. Other studies have confirmed that the inhibition of autophagy promotes the sensitization of cancer cells to anticancer therapy [146,147]. Also, under hypoxia and metabolic stress, necrosis happens in carcinoma and can induce inflammation and enhance the recruits of inflammatory cell, and then promotes pro-metastasis $[148,149]$. Autophagy inhibits necrosis and inflammation at cancer sites by producing cellular energy and metabolic precursors, followed by the suppression of metastasis. EMT is another important factor in cancer metastasis. Some regulators of EMT can promote EMT through the loss of cell-cell adhesion and associations with autophagy. One study suggested that defects of autophagy enhance EMT by stabilizing TWIST1 [150].

In colorectal cancer stem-cells, the maintenance of pluripotency in CSCs requires complex responses, such as energy metabolism, during a variety of stressful conditions. Autophagy is one of the responses to stressful conditions and maintains pluripotency in colorectal CSCs. Sharif et al. have demonstrated that the knockdown of autophagy-related proteins, ATG5 and ATG7, inhibits autophagy and reduces stemness markers, such as Oct4, SOX2, and Nanog. As a result, reduced autophagy leads to suppressed cell-proliferation and enhanced cell-senescence in colorectal CSCs [139]. Another study has indicated that induction of autophagy by overexpressing prion protein induces resistance to anticancer reagents and sustains stemness in colorectal CSCs [151]. These results indicate that autophagy is a core regulator of pluripotency maintenance and drug resistance in CSCs (Figure 3).

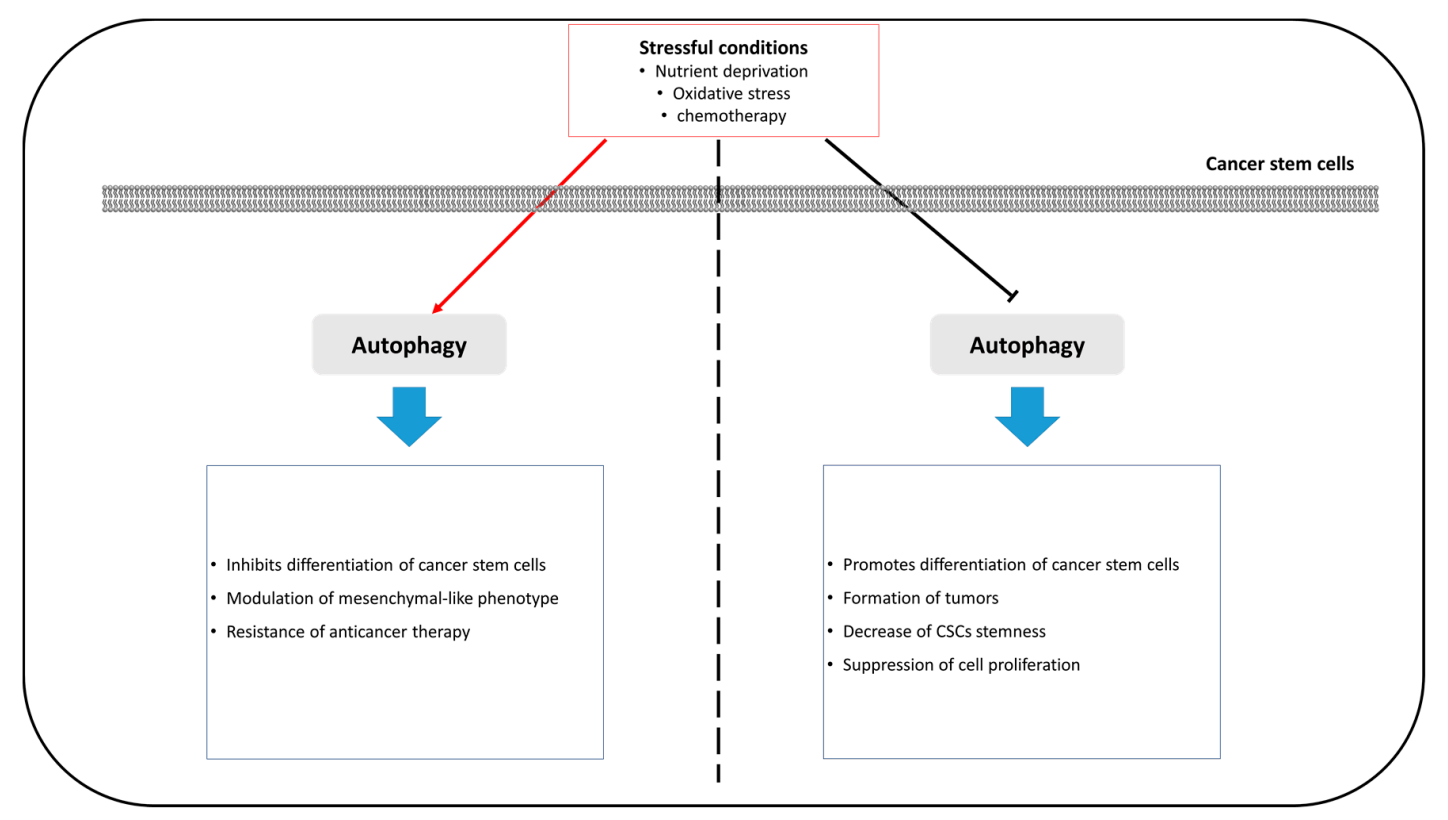

Figure 3. A schematic diagram of the autophagy roles in cancer stem-cells. 


\section{Targeting Autophagy in Cancer Therapy}

Many studies have indicated that autophagy functions as both a tumor suppressor and promoter [152]. The modulation of autophagy is a promising potential strategy to enhance cancer therapy. A previous study has identified drugs targeting all steps of the autophagic processes, from the initiation of the autophagosome to the degradation step [153]. In addition, many studies have confirmed that autophagy plays crucial roles in anticancer therapy, including the acquisition of resistance for anticancer therapy [154-157]. Autophagy enhanced by chemotherapy decreases cell death, increases cancer-cell survival, and is associated with drug resistance in cancer. A previous study found that autophagy facilitates cancer-cell survival and drug resistance to anticancer reagents and maintains stem cell-like properties in hepatocellular carcinoma [158]. Another study indicates that the suppression of autophagy leads to promotion of apoptosis and therapeutic effects of anticancer therapy [159]. In addition, use of the autophagy inhibitor chloroquine can enhance apoptosis and the therapeutic effects of photososan-II-mediated photodynamic therapy (PS-PDT) in colorectal cancer cells [160]. Much evidence supports autophagy modulation as a promising and potential therapeutic target.

Some autophagy regulators, such as rapamycin, rapamycin water-soluble derivatives (temsirolimus and everolimus), chloroquine (CQ: antimalarial agent), and hydroxychloroquine (HCQ: CQ derivative), are used in cancer therapy. Temsirolimus and everolimus, which inhibit mTORC1 and induce autophagy, are approved by the Food and Drug Administration (FDA) for cancer therapy. Everolimus is used to treat progressive neuroendocrine tumors of pancreatic origin (PNET) and breast cancer combined with exemestance [161]. In addition, temsirolimus is used to treat relapsed or refractory mantle-cell lymphoma in the European Union [162-164], while rapamycin is used in coronary stents and rare pulmonary diseases $[165,166]$.

Both CQ and HCQ, which have previously been used to prevent and treat malaria, are lysosomal inhibitors and directly inhibited autophagy via alteration of lysosomal $\mathrm{pH}$, inhibition of autophagic degradation, and accumulation of autophagosomes [167-169]. Preclinical studies have shown that CQ or HCQ can suppress cancer-cell growth via the inhibition of autophagy in bladder cancer and pancreatic adenocarcinoma $[170,171]$. In addition, some studies have indicated that these reagents enhance the therapeutic effects of chemotherapy through the inhibition of autophagy-mediated resistance to cancer therapy $[123,172,173]$.

Moreover, Lys05 is a water-soluble analog of HCQ and was developed as a new lysosometropic agent [5]. It functions at a low dose and increases the $\mathrm{pH}$ of the lysosome, resulting in autophagy inhibition [174]. Lys05 showed higher anticancer effects than HCQ in vitro and in vivo in melanoma and colon cancer xenograft models [175]. Additionally, Lys05 combined with a BRAF inhibitor effectively inhibited cancer in vivo [176]. Therefore, the development of autophagy-specific inhibitors is a new therapeutic strategy for anticancer therapy.

Other autophagy-related drugs have been developed for anticancer therapy. Spautin-1 inhibits autophagy and leads to the induction of proteasomal removal of class III PI3K kinase complexes [177]. The pro-apoptotic effect of Spautin-1 is related to GSK3 $\beta$ and affects a crucial downstream effector of PI3K/Akt [178]. Therefore, Spautin-1 is a potential therapeutic agent for anticancer therapy. Additionally, SAR405 is a kinase inhibitor of Vps18 and Vps34 and impairs lysosomal function [179], as well as influences the interaction between the late endosome and lysosome [180]. SAR405 combined with everolimus enhances the inhibition of cancer proliferation in renal cancer cell lines [179]. These results indicate that SAR405 has anticancer therapeutic effects as a Vps34 inhibitor.

\section{Conclusions}

Autophagy is regulated by complex intracellular processes under stressful conditions, including nutrient deprivation, the presence of damaged organelles, and anticancer therapy. Many studies have found that autophagy plays dual roles in cell survival and cell death in the context of tumor initiation and development. Studies on autophagy-deficient mouse models indicate that 
the basal levels of autophagy can suppress tumor formation at the initiation of tumor development. However, autophagy promotes cancer progression in many cancers. Many studies demonstrate that autophagy supplies sufficient nutrients that enable cancer cell growth. However, some studies indicated that autophagy also suppresses tumor growth, initiation, and development. Some autophagy-related genes plays roles in non-autophagy functions in addition to autophagy-related functions [181]. FIP200, an autophagy-related protein, interacts with ATG 13 and induces autophagy. Although mutations in FIP200 induce autophagy, FIP200 plays a role in embryogenesis via the protection of apoptosis [181]. Another study revealed that the loss of autophagy-related genes increased the aggressive development of HER2-positive breast cancer [182]. Increased autophagy induces the interaction of Beclin 1 and HER2, resulting in increased tumorigenesis. In BECN1 mutant mice, augmentation of autophagy did not induce HER2-mediated tumorigenesis. Therefore, in order to fully apply the properties of autophagy in cancer therapy, additional study on its role in the disease within a variety of biological fields is necessary.

CSCs have the ability to self-renew and form cancers, and the presence of CSCs contributes to resistance to anticancer therapy, recurrence, and metastasis. Autophagy mitigates several stressful conditions and promotes resistance to anticancer therapy. Moreover, autophagy regulates maintenance of pluripotency in CSCs and leads to failure of anticancer therapy. Therefore, autophagy is a potential therapeutic target to address the resistance of anticancer therapy, recurrence, and metastasis. However, additional study is required before CSCs can be treated by modulating autophagy. Regulation of autophagy using autophagy modulators alone has not improved the therapeutic effects of anticancer reagents; on the contrary, it has supplied nutrients for cancer cells. Thus, clinical trials that target autophagy through a combination of autophagy modulations and anticancer reagents are necessary to investigate autophagy as a potentially effective therapeutic strategy in anticancer therapy.

Funding: This work was supported by a National Research Foundation grant funded by the Korean government (Grant number: NRF-2016R1D1A3B01007727 and NRF-2017M3A9B4032528).

Acknowledgments: This work was supported by a National Research Foundation grant funded by the Korean government (NRF-2016R1D1A3B01007727 and NRF-2017M3A9B4032528). The funders of the grant had no role in the manuscript design, the decision to publish, or the preparation of the manuscript.

Conflicts of Interest: The authors declare no conflict of interest.

\section{References}

1. Mizushima, N. Autophagy: Process and function. Genes Dev. 2007, 21, 2861-2873. [CrossRef] [PubMed]

2. Mizushima, N. The pleiotropic role of autophagy: From protein metabolism to bactericide. Cell Death Differ. 2005, 12 (Suppl. 2), 1535-1541. [CrossRef] [PubMed]

3. Ameisen, J.C. On the origin, evolution, and nature of programmed cell death: A timeline of four billion years. Cell Death Differ. 2002, 9, 367-393. [CrossRef] [PubMed]

4. Lorin, S.; Hamai, A.; Mehrpour, M.; Codogno, P. Autophagy regulation and its role in cancer. Semin. Cancer Biol. 2013, 23, 361-379. [CrossRef] [PubMed]

5. White, E. Deconvoluting the context-dependent role for autophagy in cancer. Nat. Rev. Cancer 2012, 12, 401-410. [CrossRef] [PubMed]

6. Maiuri, M.C.; Tasdemir, E.; Criollo, A.; Morselli, E.; Vicencio, J.M.; Carnuccio, R.; Kroemer, G. Control of autophagy by oncogenes and tumor suppressor genes. Cell Death Differ. 2009, 16, 87-93. [CrossRef] [PubMed]

7. Botti, J.; Djavaheri-Mergny, M.; Pilatte, Y.; Codogno, P. Autophagy signaling and the cogwheels of cancer. Autophagy 2006, 2, 67-73. [CrossRef] [PubMed]

8. Lim, K.H.; Staudt, L.M. Toll-like receptor signaling. Cold Spring Harbor Perspect. Biol. 2013, 5, a011247. [CrossRef] [PubMed]

9. Salminen, A.; Kaarniranta, K.; Kauppinen, A. Beclin 1 interactome controls the crosstalk between apoptosis, autophagy and inflammasome activation: Impact on the aging process. Ageing Res. Rev. 2013, 12, 520-534. [CrossRef] [PubMed] 
10. Rosenfeldt, M.T.; Ryan, K.M. The multiple roles of autophagy in cancer. Carcinogenesis 2011, 32, 955-963. [CrossRef] [PubMed]

11. Gewirtz, D.A. The four faces of autophagy: Implications for cancer therapy. Cancer Res. 2014, 74, $647-651$. [CrossRef] [PubMed]

12. Russell, R.C.; Yuan, H.X.; Guan, K.L. Autophagy regulation by nutrient signaling. Cell Res. 2014, $24,42-57$. [CrossRef] [PubMed]

13. Mizushima, N.; Levine, B. Autophagy in mammalian development and differentiation. Nat. Cell Biol. 2010, 12, 823-830. [CrossRef] [PubMed]

14. Galluzzi, L.; Pietrocola, F.; Bravo-San Pedro, J.M.; Amaravadi, R.K.; Baehrecke, E.H.; Cecconi, F.; Codogno, P.; Debnath, J.; Gewirtz, D.A.; Karantza, V.; et al. Autophagy in malignant transformation and cancer progression. EMBO J. 2015, 34, 856-880. [CrossRef] [PubMed]

15. Ktistakis, N.T.; Tooze, S.A. Digesting the Expanding Mechanisms of Autophagy. Trends Cell Biol. 2016, 26, 624-635. [CrossRef] [PubMed]

16. Amaravadi, R.; Kimmelman, A.C.; White, E. Recent insights into the function of autophagy in cancer. Genes Dev. 2016, 30, 1913-1930. [CrossRef] [PubMed]

17. He, L.; Zhang, J.; Zhao, J.; Ma, N.; Kim, S.W.; Qiao, S.; Ma, X. Autophagy: The Last Defense against Cellular Nutritional Stress. Adv. Nutr. 2018, 9, 493-504. [CrossRef] [PubMed]

18. Fang, Y.; Tan, J.; Zhang, Q. Signaling pathways and mechanisms of hypoxia-induced autophagy in the animal cells. Cell Biol. Int. 2015, 39, 891-898. [CrossRef] [PubMed]

19. Wu, H.M.; Jiang, Z.F.; Ding, P.S.; Shao, L.J.; Liu, R.Y. Hypoxia-induced autophagy mediates cisplatin resistance in lung cancer cells. Sci. Rep. 2015, 5, 12291. [CrossRef] [PubMed]

20. Yu, L.; Chen, Y.; Tooze, S.A. Autophagy pathway: Cellular and molecular mechanisms. Autophagy 2018, 14, 207-215. [CrossRef] [PubMed]

21. Phadwal, K.; Watson, A.S.; Simon, A.K. Tightrope act: Autophagy in stem cell renewal, differentiation, proliferation, and aging. Cell. Mol. Life Sci. 2013, 70, 89-103. [CrossRef] [PubMed]

22. Vessoni, A.T.; Muotri, A.R.; Okamoto, O.K. Autophagy in stem cell maintenance and differentiation. Stem Cells Dev. 2012, 21, 513-520. [CrossRef] [PubMed]

23. Dibble, C.C.; Manning, B.D. Signal integration by mTORC1 coordinates nutrient input with biosynthetic output. Nat. Cell Biol. 2013, 15, 555-564. [CrossRef] [PubMed]

24. Populo, H.; Lopes, J.M.; Soares, P. The mTOR signalling pathway in human cancer. Int. J. Mol. Sci. 2012, 13, 1886-1918. [CrossRef] [PubMed]

25. Kim, Y.C.; Guan, K.L. mTOR: A pharmacologic target for autophagy regulation. J. Clin. Investig. 2015, 125, 25-32. [CrossRef] [PubMed]

26. Kim, J.; Kundu, M.; Viollet, B.; Guan, K.L. AMPK and mTOR regulate autophagy through direct phosphorylation of Ulk1. Nat. Cell Biol. 2011, 13, 132-141. [CrossRef] [PubMed]

27. Scott, R.C.; Schuldiner, O.; Neufeld, T.P. Role and regulation of starvation-induced autophagy in the Drosophila fat body. Dev. Cell 2004, 7, 167-178. [CrossRef] [PubMed]

28. Martina, J.A.; Chen, Y.; Gucek, M.; Puertollano, R. MTORC1 functions as a transcriptional regulator of autophagy by preventing nuclear transport of TFEB. Autophagy 2012, 8, 903-914. [CrossRef] [PubMed]

29. Torii, S.; Yoshida, T.; Arakawa, S.; Honda, S.; Nakanishi, A.; Shimizu, S. Identification of PPM1D as an essential Ulk1 phosphatase for genotoxic stress-induced autophagy. EMBO Rep. 2016, 17, 1552-1564. [CrossRef] [PubMed]

30. Itakura, E.; Kishi, C.; Inoue, K.; Mizushima, N. Beclin 1 forms two distinct phosphatidylinositol 3-kinase complexes with mammalian Atg14 and UVRAG. Mol. Biol. Cell 2008, 19, 5360-5372. [CrossRef] [PubMed]

31. Maiuri, M.C.; Criollo, A.; Kroemer, G. Crosstalk between apoptosis and autophagy within the Beclin 1 interactome. EMBO J. 2010, 29, 515-516. [CrossRef] [PubMed]

32. Mochida, K.; Oikawa, Y.; Kimura, Y.; Kirisako, H.; Hirano, H.; Ohsumi, Y.; Nakatogawa, H. Receptor-mediated selective autophagy degrades the endoplasmic reticulum and the nucleus. Nature 2015, 522, 359-362. [CrossRef] [PubMed]

33. Carlsson, S.R.; Simonsen, A. Membrane dynamics in autophagosome biogenesis. J. Cell Sci. 2015, 128, $193-205$. [CrossRef] [PubMed] 
34. Kabeya, Y.; Mizushima, N.; Ueno, T.; Yamamoto, A.; Kirisako, T.; Noda, T.; Kominami, E.; Ohsumi, Y.; Yoshimori, T. LC3, a mammalian homologue of yeast Apg8p, is localized in autophagosome membranes after processing. EMBO J. 2000, 19, 5720-5728. [CrossRef] [PubMed]

35. Stolz, A.; Ernst, A.; Dikic, I. Cargo recognition and trafficking in selective autophagy. Nat. Cell Biol. 2014, 16, 495-501. [CrossRef] [PubMed]

36. Wild, P.; McEwan, D.G.; Dikic, I. The LC3 interactome at a glance. J. Cell Sci. 2014, 127, 3-9. [CrossRef] [PubMed]

37. Thurston, T.L.; Boyle, K.B.; Allen, M.; Ravenhill, B.J.; Karpiyevich, M.; Bloor, S.; Kaul, A.; Noad, J.; Foeglein, A.; Matthews, S.A.; et al. Recruitment of TBK1 to cytosol-invading Salmonella induces WIPI2-dependent antibacterial autophagy. EMBO J. 2016, 35, 1779-1792. [CrossRef] [PubMed]

38. White, E. The role for autophagy in cancer. J. Clin. Investig. 2015, 125, 42-46. [CrossRef] [PubMed]

39. Mathew, R.; Khor, S.; Hackett, S.R.; Rabinowitz, J.D.; Perlman, D.H.; White, E. Functional role of autophagy-mediated proteome remodeling in cell survival signaling and innate immunity. Mol. Cell 2014, 55, 916-930. [CrossRef] [PubMed]

40. Karsli-Uzunbas, G.; Guo, J.Y.; Price, S.; Teng, X.; Laddha, S.V.; Khor, S.; Kalaany, N.Y.; Jacks, T.; Chan, C.S.; Rabinowitz, J.D.; et al. Autophagy is required for glucose homeostasis and lung tumor maintenance. Cancer Discov. 2014, 4, 914-927. [CrossRef] [PubMed]

41. Comel, A.; Sorrentino, G.; Capaci, V.; Del Sal, G. The cytoplasmic side of p53's oncosuppressive activities. FEBS Lett. 2014, 588, 2600-2609. [CrossRef] [PubMed]

42. Choi, A.M.; Ryter, S.W.; Levine, B. Autophagy in human health and disease. N. Engl. J. Med. 2013, 368, 651-662. [CrossRef] [PubMed]

43. Wang, T.; Hu, J.; Luo, H.; Li, H.; Zhou, J.; Zhou, L.; Wei, S. Photosensitizer and Autophagy Promoter Coloaded ROS-Responsive Dendrimer-Assembled Carrier for Synergistic Enhancement of Tumor Growth Suppression. Small 2018, 14, e1802337. [CrossRef] [PubMed]

44. Qu, X.; Yu, J.; Bhagat, G.; Furuya, N.; Hibshoosh, H.; Troxel, A.; Rosen, J.; Eskelinen, E.L.; Mizushima, N.; Ohsumi, Y.; et al. Promotion of tumorigenesis by heterozygous disruption of the beclin 1 autophagy gene. J. Clin. Investig. 2003, 112, 1809-1820. [CrossRef] [PubMed]

45. Takahashi, Y.; Coppola, D.; Matsushita, N.; Cualing, H.D.; Sun, M.; Sato, Y.; Liang, C.; Jung, J.U.; Cheng, J.Q.; Mule, J.J.; et al. Bif-1 interacts with Beclin 1 through UVRAG and regulates autophagy and tumorigenesis. Nat. Cell Biol. 2007, 9, 1142-1151. [CrossRef] [PubMed]

46. Coppola, D.; Khalil, F.; Eschrich, S.A.; Boulware, D.; Yeatman, T.; Wang, H.G. Down-regulation of Bax-interacting factor-1 in colorectal adenocarcinoma. Cancer 2008, 113, 2665-2670. [CrossRef] [PubMed]

47. Lee, J.W.; Jeong, E.G.; Soung, Y.H.; Nam, S.W.; Lee, J.Y.; Yoo, N.J.; Lee, S.H. Decreased expression of tumour suppressor Bax-interacting factor-1 (Bif-1), a Bax activator, in gastric carcinomas. Pathology 2006, 38, 312-315. [CrossRef] [PubMed]

48. He, S.; Zhao, Z.; Yang, Y.; O'Connell, D.; Zhang, X.; Oh, S.; Ma, B.; Lee, J.H.; Zhang, T.; Varghese, B.; et al. Truncating mutation in the autophagy gene UVRAG confers oncogenic properties and chemosensitivity in colorectal cancers. Nat. Commun. 2015, 6, 7839. [CrossRef] [PubMed]

49. Perera, R.M.; Stoykova, S.; Nicolay, B.N.; Ross, K.N.; Fitamant, J.; Boukhali, M.; Lengrand, J.; Deshpande, V.; Selig, M.K.; Ferrone, C.R.; et al. Transcriptional control of autophagy-lysosome function drives pancreatic cancer metabolism. Nature 2015, 524, 361-365. [CrossRef] [PubMed]

50. Yang, A.; Rajeshkumar, N.V.; Wang, X.; Yabuuchi, S.; Alexander, B.M.; Chu, G.C.; Von Hoff, D.D.; Maitra, A.; Kimmelman, A.C. Autophagy is critical for pancreatic tumor growth and progression in tumors with p53 alterations. Cancer Discov. 2014, 4, 905-913. [CrossRef] [PubMed]

51. Tang, D.; Kang, R.; Livesey, K.M.; Cheh, C.W.; Farkas, A.; Loughran, P.; Hoppe, G.; Bianchi, M.E.; Tracey, K.J.; Zeh, H.J., 3rd; et al. Endogenous HMGB1 regulates autophagy. J. Cell Biol. 2010, 190, 881-892. [CrossRef] [PubMed]

52. Shen, Y.; Li, D.D.; Wang, L.L.; Deng, R.; Zhu, X.F. Decreased expression of autophagy-related proteins in malignant epithelial ovarian cancer. Autophagy 2008, 4, 1067-1068. [CrossRef] [PubMed]

53. Liang, X.H.; Jackson, S.; Seaman, M.; Brown, K.; Kempkes, B.; Hibshoosh, H.; Levine, B. Induction of autophagy and inhibition of tumorigenesis by beclin 1. Nature 1999, 402, 672-676. [CrossRef] [PubMed] 
54. Yue, Z.; Jin, S.; Yang, C.; Levine, A.J.; Heintz, N. Beclin 1, an autophagy gene essential for early embryonic development, is a haploinsufficient tumor suppressor. Proc. Natl. Acad. Sci. USA 2003, 100, 15077-15082. [CrossRef] [PubMed]

55. Cai, M.; Hu, Z.; Liu, J.; Gao, J.; Liu, C.; Liu, D.; Tan, M.; Zhang, D.; Lin, B. Beclin 1 expression in ovarian tissues and its effects on ovarian cancer prognosis. Int. J. Mol. Sci. 2014, 15, 5292-5303. [CrossRef] [PubMed]

56. Qiu, D.M.; Wang, G.L.; Chen, L.; Xu, Y.Y.; He, S.; Cao, X.L.; Qin, J.; Zhou, J.M.; Zhang, Y.X.; E, Q. The expression of beclin-1, an autophagic gene, in hepatocellular carcinoma associated with clinical pathological and prognostic significance. BMC Cancer 2014, 14, 327. [CrossRef] [PubMed]

57. Zhang, Z.; Shao, Z.; Xiong, L.; Che, B.; Deng, C.; Xu, W. Expression of Beclin1 in osteosarcoma and the effects of down-regulation of autophagy on the chemotherapeutic sensitivity. J. Huazhong Univ. Sci. Technol. Med. Sci. 2009, 29, 737-740. [CrossRef] [PubMed]

58. Huang, X.; Bai, H.M.; Chen, L.; Li, B.; Lu, Y.C. Reduced expression of LC3B-II and Beclin 1 in glioblastoma multiforme indicates a down-regulated autophagic capacity that relates to the progression of astrocytic tumors. J. Clin. Neurosci. 2010, 17, 1515-1519. [CrossRef] [PubMed]

59. Morselli, E.; Galluzzi, L.; Kepp, O.; Vicencio, J.M.; Criollo, A.; Maiuri, M.C.; Kroemer, G. Anti- and pro-tumor functions of autophagy. Biochim. Biophys. Acta 2009, 1793, 1524-1532. [CrossRef] [PubMed]

60. Kung, C.P.; Budina, A.; Balaburski, G.; Bergenstock, M.K.; Murphy, M. Autophagy in tumor suppression and cancer therapy. Crit. Rev. Eukaryot. Gene Expr. 2011, 21, 71-100. [CrossRef] [PubMed]

61. Kim, M.S.; Jeong, E.G.; Ahn, C.H.; Kim, S.S.; Lee, S.H.; Yoo, N.J. Frameshift mutation of UVRAG, an autophagy-related gene, in gastric carcinomas with microsatellite instability. Hum. Pathol. 2008, 39, 1059-1063. [CrossRef] [PubMed]

62. Takamura, A.; Komatsu, M.; Hara, T.; Sakamoto, A.; Kishi, C.; Waguri, S.; Eishi, Y.; Hino, O.; Tanaka, K.; Mizushima, N. Autophagy-deficient mice develop multiple liver tumors. Genes Dev. 2011, 25, 795-800. [CrossRef] [PubMed]

63. Kuma, A.; Hatano, M.; Matsui, M.; Yamamoto, A.; Nakaya, H.; Yoshimori, T.; Ohsumi, Y.; Tokuhisa, T.; Mizushima, N. The role of autophagy during the early neonatal starvation period. Nature 2004, 432, 1032-1036. [CrossRef] [PubMed]

64. Komatsu, M.; Waguri, S.; Ueno, T.; Iwata, J.; Murata, S.; Tanida, I.; Ezaki, J.; Mizushima, N.; Ohsumi, Y.; Uchiyama, Y.; et al. Impairment of starvation-induced and constitutive autophagy in Atg7-deficient mice. J. Cell Biol. 2005, 169, 425-434. [CrossRef] [PubMed]

65. Saitoh, T.; Fujita, N.; Jang, M.H.; Uematsu, S.; Yang, B.G.; Satoh, T.; Omori, H.; Noda, T.; Yamamoto, N.; Komatsu, M.; et al. Loss of the autophagy protein Atg16L1 enhances endotoxin-induced IL-1beta production. Nature 2008, 456, 264-268. [CrossRef] [PubMed]

66. Sou, Y.S.; Waguri, S.; Iwata, J.; Ueno, T.; Fujimura, T.; Hara, T.; Sawada, N.; Yamada, A.; Mizushima, N.; Uchiyama, Y.; et al. The Atg8 conjugation system is indispensable for proper development of autophagic isolation membranes in mice. Mol. Biol. Cell 2008, 19, 4762-4775. [CrossRef] [PubMed]

67. Marino, G.; Salvador-Montoliu, N.; Fueyo, A.; Knecht, E.; Mizushima, N.; Lopez-Otin, C. Tissue-specific autophagy alterations and increased tumorigenesis in mice deficient in Atg4C/autophagin-3. J. Biol. Chem. 2007, 282, 18573-18583. [CrossRef] [PubMed]

68. Moloney, J.N.; Cotter, T.G. ROS signalling in the biology of cancer. Semin. Cell Dev. Biol. 2018, 80, 50-64. [CrossRef] [PubMed]

69. Avalos, Y.; Canales, J.; Bravo-Sagua, R.; Criollo, A.; Lavandero, S.; Quest, A.F. Tumor suppression and promotion by autophagy. BioMed Res. Int. 2014, 2014, 603980. [CrossRef] [PubMed]

70. Filomeni, G.; De Zio, D.; Cecconi, F. Oxidative stress and autophagy: The clash between damage and metabolic needs. Cell Death Differ. 2015, 22, 377-388. [CrossRef] [PubMed]

71. Luo, T.; Fu, J.; Xu, A.; Su, B.; Ren, Y.; Li, N.; Zhu, J.; Zhao, X.; Dai, R.; Cao, J.; et al. PSMD10/gankyrin induces autophagy to promote tumor progression through cytoplasmic interaction with ATG7 and nuclear transactivation of ATG7 expression. Autophagy 2016, 12, 1355-1371. [CrossRef] [PubMed]

72. Liu, M.; Jiang, L.; Fu, X.; Wang, W.; Ma, J.; Tian, T.; Nan, K.; Liang, X. Cytoplasmic liver kinase B1 promotes the growth of human lung adenocarcinoma by enhancing autophagy. Cancer Sci. 2018, 109, 3055-3067. [CrossRef] [PubMed]

73. White, E.; DiPaola, R.S. The double-edged sword of autophagy modulation in cancer. Clin. Cancer Res. 2009, 15, 5308-5316. [CrossRef] [PubMed] 
74. Degenhardt, K.; Mathew, R.; Beaudoin, B.; Bray, K.; Anderson, D.; Chen, G.; Mukherjee, C.; Shi, Y.; Gelinas, C.; Fan, Y.; et al. Autophagy promotes tumor cell survival and restricts necrosis, inflammation, and tumorigenesis. Cancer Cell 2006, 10, 51-64. [CrossRef] [PubMed]

75. Rabinowitz, J.D.; White, E. Autophagy and metabolism. Science 2010, 330, 1344-1348. [CrossRef] [PubMed]

76. Liu, E.Y.; Ryan, K.M. Autophagy and cancer-Issues we need to digest. J. Cell Sci. 2012, 125, $2349-2358$. [CrossRef] [PubMed]

77. Boya, P.; Reggiori, F.; Codogno, P. Emerging regulation and functions of autophagy. Nat. Cell Biol. 2013, 15, 713-720. [CrossRef] [PubMed]

78. Wei, H.; Wei, S.; Gan, B.; Peng, X.; Zou, W.; Guan, J.L. Suppression of autophagy by FIP200 deletion inhibits mammary tumorigenesis. Genes Dev. 2011, 25, 1510-1527. [CrossRef] [PubMed]

79. Zhu, D.; Zhou, J.; Zhao, J.; Jiang, G.; Zhang, X.; Zhang, Y.; Dong, M. ZC3H13 suppresses colorectal cancer proliferation and invasion via inactivating Ras-ERK signaling. J. Cell. Physiol. 2018. [CrossRef] [PubMed]

80. Su, C.C. Tanshinone IIA can inhibit MiaPaCa2 human pancreatic cancer cells by dual blockade of the Ras/Raf/MEK/ERK and PI3K/AKT/mTOR pathways. Oncol. Rep. 2018, 40, 3102-3111. [PubMed]

81. Natan, S.; Tsarfaty, G.; Horev, J.; Haklai, R.; Kloog, Y.; Tsarfaty, I. Interplay Between HGF/SF-Met-Ras Signaling, Tumor Metabolism and Blood Flow as a Potential Target for Breast Cancer Therapy. Oncoscience 2014, 1, 30-38. [CrossRef] [PubMed]

82. Guo, J.Y.; Chen, H.Y.; Mathew, R.; Fan, J.; Strohecker, A.M.; Karsli-Uzunbas, G.; Kamphorst, J.J.; Chen, G.; Lemons, J.M.; Karantza, V.; et al. Activated Ras requires autophagy to maintain oxidative metabolism and tumorigenesis. Genes Dev. 2011, 25, 460-470. [CrossRef] [PubMed]

83. Karnoub, A.E.; Weinberg, R.A. Ras oncogenes: Split personalities. Nat. Rev. Mol. Cell Biol. 2008, 9, 517-531. [CrossRef] [PubMed]

84. Goel, S.; Huang, J.; Klampfer, L. K-Ras, intestinal homeostasis and colon cancer. Curr. Clin. Pharmacol. 2015, 10, 73-81. [CrossRef] [PubMed]

85. Masliah-Planchon, J.; Garinet, S.; Pasmant, E. RAS-MAPK pathway epigenetic activation in cancer: MiRNAs in action. Oncotarget 2016, 7, 38892-38907. [CrossRef] [PubMed]

86. Goncalves, P.R.; Rocha-Brito, K.J.; Fernandes, M.R.; Abrantes, J.L.; Duran, N.; Ferreira-Halder, C.V. Violacein induces death of RAS-mutated metastatic melanoma by impairing autophagy process. Tumour Biol. 2016, 37, 14049-14058. [CrossRef] [PubMed]

87. Shin, J.H.; Park, C.W.; Yoon, G.; Hong, S.M.; Choi, K.Y. NNMT depletion contributes to liver cancer cell survival by enhancing autophagy under nutrient starvation. Oncogenesis 2018, 7, 58. [CrossRef] [PubMed]

88. Guo, J.Y.; Karsli-Uzunbas, G.; Mathew, R.; Aisner, S.C.; Kamphorst, J.J.; Strohecker, A.M.; Chen, G.; Price, S.; Lu, W.; Teng, X.; et al. Autophagy suppresses progression of K-ras-induced lung tumors to oncocytomas and maintains lipid homeostasis. Genes Dev. 2013, 27, 1447-1461. [CrossRef] [PubMed]

89. Guo, J.Y.; White, E. Autophagy is required for mitochondrial function, lipid metabolism, growth, and fate of KRAS(G12D)-driven lung tumors. Autophagy 2013, 9, 1636-1638. [CrossRef] [PubMed]

90. Bryant, K.L.; Mancias, J.D.; Kimmelman, A.C.; Der, C.J. KRAS: Feeding pancreatic cancer proliferation. Trends Biochem. Sci. 2014, 39, 91-100. [CrossRef] [PubMed]

91. Vaupel, P.; Mayer, A. Hypoxia and anemia: Effects on tumor biology and treatment resistance. Transfus. Clin. Biol. 2005, 12, 5-10. [CrossRef] [PubMed]

92. Daskalaki, I.; Gkikas, I.; Tavernarakis, N. Hypoxia and Selective Autophagy in Cancer Development and Therapy. Front. Cell Dev. Biol. 2018, 6, 104. [CrossRef] [PubMed]

93. Li, Y.Y.; Feun, L.G.; Thongkum, A.; Tu, C.H.; Chen, S.M.; Wangpaichitr, M.; Wu, C.; Kuo, M.T.; Savaraj, N. Autophagic Mechanism in Anti-Cancer Immunity: Its Pros and Cons for Cancer Therapy. Int. J. Mol. Sci. 2017, 18, 1297. [CrossRef] [PubMed]

94. Mazure, N.M.; Pouyssegur, J. Hypoxia-induced autophagy: Cell death or cell survival? Curr. Opin. Cell Biol. 2010, 22, 177-180. [CrossRef] [PubMed]

95. Masoud, G.N.; Li, W. HIF-1alpha pathway: Role, regulation and intervention for cancer therapy. Acta Pharm. Sin. B 2015, 5, 378-389. [CrossRef] [PubMed]

96. Denko, N.C. Hypoxia, HIF1 and glucose metabolism in the solid tumour. Nat. Rev. Cancer 2008, 8, 705-713. [CrossRef] [PubMed]

97. Franklin, R.A.; Liao, W.; Sarkar, A.; Kim, M.V.; Bivona, M.R.; Liu, K.; Pamer, E.G.; Li, M.O. The cellular and molecular origin of tumor-associated macrophages. Science 2014, 344, 921-925. [CrossRef] [PubMed] 
98. Lin, W.W.; Karin, M. A cytokine-mediated link between innate immunity, inflammation, and cancer. J. Clin. Investig. 2007, 117, 1175-1183. [CrossRef] [PubMed]

99. Kim, M.J.; Yoon, J.H.; Ryu, J.H. Mitophagy: A balance regulator of NLRP3 inflammasome activation. BMB Rep. 2016, 49, 529-535. [CrossRef] [PubMed]

100. Kenific, C.M.; Thorburn, A.; Debnath, J. Autophagy and metastasis: Another double-edged sword. Curr. Opin. Cell Biol. 2010, 22, 241-245. [CrossRef] [PubMed]

101. Sosa, M.S.; Bragado, P.; Aguirre-Ghiso, J.A. Mechanisms of disseminated cancer cell dormancy: An awakening field. Nat. Rev. Cancer 2014, 14, 611-622. [CrossRef] [PubMed]

102. Langley, R.R.; Fidler, I.J. The seed and soil hypothesis revisited-The role of tumor-stroma interactions in metastasis to different organs. Int. J. Cancer 2011, 128, 2527-2535. [CrossRef] [PubMed]

103. Hamurcu, Z.; Delibasi, N.; Gecene, S.; Sener, E.F.; Donmez-Altuntas, H.; Ozkul, Y.; Canatan, H.; Ozpolat, B. Targeting LC3 and Beclin-1 autophagy genes suppresses proliferation, survival, migration and invasion by inhibition of Cyclin-D1 and uPAR/Integrin beta1/Src signaling in triple negative breast cancer cells. J. Cancer Res. Clin. Oncol. 2018, 144, 415-430. [CrossRef] [PubMed]

104. Liu, H.; He, Z.; von Rutte, T.; Yousefi, S.; Hunger, R.E.; Simon, H.U. Down-regulation of autophagy-related protein 5 (ATG5) contributes to the pathogenesis of early-stage cutaneous melanoma. Sci. Transl. Med. 2013, 5, 202ra123. [CrossRef] [PubMed]

105. Hashimoto, I.; Koizumi, K.; Tatematsu, M.; Minami, T.; Cho, S.; Takeno, N.; Nakashima, A.; Sakurai, H.; Saito, S.; Tsukada, K.; et al. Blocking on the CXCR4/mTOR signalling pathway induces the anti-metastatic properties and autophagic cell death in peritoneal disseminated gastric cancer cells. Eur. J. Cancer 2008, 44, 1022-1029. [CrossRef] [PubMed]

106. Vanharanta, S.; Massague, J. Origins of metastatic traits. Cancer Cell 2013, 24, 410-421. [CrossRef] [PubMed]

107. Guadamillas, M.C.; Cerezo, A.; Del Pozo, M.A. Overcoming anoikis-Pathways to anchorage-independent growth in cancer. J. Cell Sci. 2011, 124, 3189-3197. [CrossRef] [PubMed]

108. Peng, Y.F.; Shi, Y.H.; Ding, Z.B.; Ke, A.W.; Gu, C.Y.; Hui, B.; Zhou, J.; Qiu, S.J.; Dai, Z.; Fan, J. Autophagy inhibition suppresses pulmonary metastasis of HCC in mice via impairing anoikis resistance and colonization of HCC cells. Autophagy 2013, 9, 2056-2068. [CrossRef] [PubMed]

109. Fung, C.; Lock, R.; Gao, S.; Salas, E.; Debnath, J. Induction of autophagy during extracellular matrix detachment promotes cell survival. Mol. Biol. Cell 2008, 19, 797-806. [CrossRef] [PubMed]

110. Kalluri, R.; Weinberg, R.A. The basics of epithelial-mesenchymal transition. J. Clin. Investig. 2009, 119, 1420-1428. [CrossRef] [PubMed]

111. Polyak, K.; Weinberg, R.A. Transitions between epithelial and mesenchymal states: Acquisition of malignant and stem cell traits. Nat. Rev. Cancer 2009, 9, 265-273. [CrossRef] [PubMed]

112. Thiery, J.P.; Acloque, H.; Huang, R.Y.; Nieto, M.A. Epithelial-mesenchymal transitions in development and disease. Cell 2009, 139, 871-890. [CrossRef] [PubMed]

113. Avivar-Valderas, A.; Bobrovnikova-Marjon, E.; Alan Diehl, J.; Bardeesy, N.; Debnath, J.; Aguirre-Ghiso, J.A. Regulation of autophagy during ECM detachment is linked to a selective inhibition of mTORC1 by PERK. Oncogene 2013, 32, 4932-4940. [CrossRef] [PubMed]

114. Cai, Q.; Yan, L.; Xu, Y. Anoikis resistance is a critical feature of highly aggressive ovarian cancer cells. Oncogene 2015, 34, 3315-3324. [CrossRef] [PubMed]

115. Mikhaylova, O.; Stratton, Y.; Hall, D.; Kellner, E.; Ehmer, B.; Drew, A.F.; Gallo, C.A.; Plas, D.R.; Biesiada, J.; Meller, J.; et al. VHL-regulated MiR-204 suppresses tumor growth through inhibition of LC3B-mediated autophagy in renal clear cell carcinoma. Cancer Cell 2012, 21, 532-546. [CrossRef] [PubMed]

116. Catalano, M.; D’Alessandro, G.; Lepore, F.; Corazzari, M.; Caldarola, S.; Valacca, C.; Faienza, F.; Esposito, V.; Limatola, C.; Cecconi, F.; et al. Autophagy induction impairs migration and invasion by reversing EMT in glioblastoma cells. Mol. Oncol. 2015, 9, 1612-1625. [CrossRef] [PubMed]

117. Gugnoni, M.; Sancisi, V.; Gandolfi, G.; Manzotti, G.; Ragazzi, M.; Giordano, D.; Tamagnini, I.; Tigano, M.; Frasoldati, A.; Piana, S.; et al. Cadherin-6 promotes EMT and cancer metastasis by restraining autophagy. Oncogene 2017, 36, 667-677. [CrossRef] [PubMed]

118. Chen, Z.; Jiang, Q.; Zhu, P.; Chen, Y.; Xie, X.; Du, Z.; Jiang, L.; Tang, W. NPRL2 enhances autophagy and the resistance to Everolimus in castration-resistant prostate cancer. Prostate 2018. [CrossRef] [PubMed] 
119. Xiao, X.; Wang, W.; Li, Y.; Yang, D.; Li, X.; Shen, C.; Liu, Y.; Ke, X.; Guo, S.; Guo, Z. HSP90AA1-mediated autophagy promotes drug resistance in osteosarcoma. J. Exp. Clin. Cancer Res. 2018, 37, 201. [CrossRef] [PubMed]

120. Malet-Martino, M.; Jolimaitre, P.; Martino, R. The prodrugs of 5-fluorouracil. Curr. Med. Chem. Anti-Cancer Agents 2002, 2, 267-310. [CrossRef] [PubMed]

121. Park, J.M.; Huang, S.; Wu, T.T.; Foster, N.R.; Sinicrope, F.A. Prognostic impact of Beclin 1, p62/sequestosome 1 and LC3 protein expression in colon carcinomas from patients receiving 5-fluorouracil as adjuvant chemotherapy. Cancer Biol. Ther. 2013, 14, 100-107. [CrossRef] [PubMed]

122. Sui, X.; Kong, N.; Wang, X.; Fang, Y.; Hu, X.; Xu, Y.; Chen, W.; Wang, K.; Li, D.; Jin, W.; et al. JNK confers 5-fluorouracil resistance in p53-deficient and mutant p53-expressing colon cancer cells by inducing survival autophagy. Sci. Rep. 2014, 4, 4694. [CrossRef] [PubMed]

123. Liang, X.; Tang, J.; Liang, Y.; Jin, R.; Cai, X. Suppression of autophagy by chloroquine sensitizes 5-fluorouracil-mediated cell death in gallbladder carcinoma cells. Cell Biosci. 2014, 4, 10. [CrossRef] [PubMed]

124. Guclu, H.; Doganlar, Z.B.; Gurlu, V.P.; Ozal, A.; Dogan, A.; Turhan, M.A.; Doganlar, O. Effects of cisplatin-5-fluorouracil combination therapy on oxidative stress, DNA damage, mitochondrial apoptosis, and death receptor signalling in retinal pigment epithelium cells. Cutaneous Ocular Toxicol. 2018, 37, 291-304. [CrossRef] [PubMed]

125. Ferreira, J.A.; Peixoto, A.; Neves, M.; Gaiteiro, C.; Reis, C.A.; Assaraf, Y.G.; Santos, L.L. Mechanisms of cisplatin resistance and targeting of cancer stem cells: Adding glycosylation to the equation. Drug Resist. Updates 2016, 24, 34-54. [CrossRef] [PubMed]

126. Wang, J.; Wu, G.S. Role of autophagy in cisplatin resistance in ovarian cancer cells. J. Biol. Chem. 2014, 289, 17163-17173. [CrossRef] [PubMed]

127. Bao, L.; Jaramillo, M.C.; Zhang, Z.; Zheng, Y.; Yao, M.; Zhang, D.D.; Yi, X. Induction of autophagy contributes to cisplatin resistance in human ovarian cancer cells. Mol. Med. Rep. 2015, 11, 91-98. [CrossRef] [PubMed]

128. Zhu, L.; Du, H.; Shi, M.; Chen, Z.; Hang, J. ATG7 deficiency promote apoptotic death induced by Cisplatin in human esophageal squamous cell carcinoma cells. Bull. Cancer 2013, 100, 15-21. [PubMed]

129. Liu, D.; Yang, Y.; Liu, Q.; Wang, J. Inhibition of autophagy by 3-MA potentiates cisplatin-induced apoptosis in esophageal squamous cell carcinoma cells. Med. Oncol. 2011, 28, 105-111. [CrossRef] [PubMed]

130. Cheng, C.Y.; Liu, J.C.; Wang, J.J.; Li, Y.H.; Pan, J.; Zhang, Y.R. Autophagy inhibition increased the anti-tumor effect of cisplatin on drug-resistant esophageal cancer cells. J. Biol. Regul. Homeost. Agents 2017, 31, 645-652. [PubMed]

131. Chen, D.S.; Mellman, I. Oncology meets immunology: The cancer-immunity cycle. Immunity 2013, 39, 1-10. [CrossRef] [PubMed]

132. Parekh, V.V.; Wu, L.; Boyd, K.L.; Williams, J.A.; Gaddy, J.A.; Olivares-Villagomez, D.; Cover, T.L.; Zong, W.X.; Zhang, J.; Van Kaer, L. Impaired autophagy, defective T cell homeostasis, and a wasting syndrome in mice with a T cell-specific deletion of Vps34. J. Immunol. 2013, 190, 5086-5101. [CrossRef] [PubMed]

133. Bronietzki, A.W.; Schuster, M.; Schmitz, I. Autophagy in T-cell development, activation and differentiation. Immunol. Cell Biol. 2015, 93, 25-34. [CrossRef] [PubMed]

134. Noman, M.Z.; Buart, S.; Van Pelt, J.; Richon, C.; Hasmim, M.; Leleu, N.; Suchorska, W.M.; Jalil, A.; Lecluse, Y.; El Hage, F.; et al. The cooperative induction of hypoxia-inducible factor-1 alpha and STAT3 during hypoxia induced an impairment of tumor susceptibility to CTL-mediated cell lysis. J. Immunol. 2009, 182, 3510-3521. [CrossRef] [PubMed]

135. Islam, F.; Qiao, B.; Smith, R.A.; Gopalan, V.; Lam, A.K. Cancer stem cell: Fundamental experimental pathological concepts and updates. Exp. Mol. Pathol. 2015, 98, 184-191. [CrossRef] [PubMed]

136. Gupta, P.B.; Chaffer, C.L.; Weinberg, R.A. Cancer stem cells: Mirage or reality? Nat. Med. 2009, 15, 1010-1012. [CrossRef] [PubMed]

137. Pan, H.; Cai, N.; Li, M.; Liu, G.H.; Izpisua Belmonte, J.C. Autophagic control of cell ‘stemness'. EMBO Mol. Med. 2013, 5, 327-331. [CrossRef] [PubMed]

138. Hou, J.; Han, Z.P.; Jing, Y.Y.; Yang, X.; Zhang, S.S.; Sun, K.; Hao, C.; Meng, Y.; Yu, F.H.; Liu, X.Q.; et al. Autophagy prevents irradiation injury and maintains stemness through decreasing ROS generation in mesenchymal stem cells. Cell Death Dis. 2013, 4, e844. [CrossRef] [PubMed] 
139. Sharif, T.; Martell, E.; Dai, C.; Kennedy, B.E.; Murphy, P.; Clements, D.R.; Kim, Y.; Lee, P.W.; Gujar, S.A. Autophagic homeostasis is required for the pluripotency of cancer stem cells. Autophagy 2017, 13, 264-284. [CrossRef] [PubMed]

140. Zhao, Y.; Huang, Q.; Yang, J.; Lou, M.; Wang, A.; Dong, J.; Qin, Z.; Zhang, T. Autophagy impairment inhibits differentiation of glioma stem/progenitor cells. Brain Res. 2010, 1313, 250-258. [CrossRef] [PubMed]

141. Lomonaco, S.L.; Finniss, S.; Xiang, C.; Lee, H.K.; Jiang, W.; Lemke, N.; Rempel, S.A.; Mikkelsen, T.; Brodie, C. Cilengitide induces autophagy-mediated cell death in glioma cells. Neuro-Oncology 2011, 13, 857-865. [CrossRef] [PubMed]

142. Al-Hajj, M.; Wicha, M.S.; Benito-Hernandez, A.; Morrison, S.J.; Clarke, M.F. Prospective identification of tumorigenic breast cancer cells. Proc. Natl. Acad. Sci. USA 2003, 100, 3983-3988. [CrossRef] [PubMed]

143. Cufi, S.; Vazquez-Martin, A.; Oliveras-Ferraros, C.; Martin-Castillo, B.; Vellon, L.; Menendez, J.A. Autophagy positively regulates the CD44(+) CD24(-/low) breast cancer stem-like phenotype. Cell Cycle 2011, 10, 3871-3885. [CrossRef] [PubMed]

144. Mai, T.T.; Moon, J.; Song, Y.; Viet, P.Q.; Phuc, P.V.; Lee, J.M.; Yi, T.H.; Cho, M.; Cho, S.K. Ginsenoside F2 induces apoptosis accompanied by protective autophagy in breast cancer stem cells. Cancer Lett. 2012, 321, 144-153. [CrossRef] [PubMed]

145. Xu, L.Z.; Long, Z.J.; Peng, F.; Liu, Y.; Xu, J.; Wang, C.; Jiang, L.; Guo, T.; Kamran, M.; Li, S.S.; et al. Aurora kinase a suppresses metabolic stress-induced autophagic cell death by activating mTOR signaling in breast cancer cells. Oncotarget 2014, 5, 7498-7511. [CrossRef] [PubMed]

146. Zhou, Y.; Rucker, E.B., 3rd; Zhou, B.P. Autophagy regulation in the development and treatment of breast cancer. Acta Biochim. Biophys. Sin. 2016, 48, 60-74. [PubMed]

147. Yeo, S.K.; Wen, J.; Chen, S.; Guan, J.L. Autophagy Differentially Regulates Distinct Breast Cancer Stem-like Cells in Murine Models via EGFR/Stat3 and Tgfbeta/Smad Signaling. Cancer Res. 2016, 76, 3397-3410. [CrossRef] [PubMed]

148. DeNardo, D.G.; Barreto, J.B.; Andreu, P.; Vasquez, L.; Tawfik, D.; Kolhatkar, N.; Coussens, L.M. CD4(+) T cells regulate pulmonary metastasis of mammary carcinomas by enhancing protumor properties of macrophages. Cancer Cell 2009, 16, 91-102. [CrossRef] [PubMed]

149. Mukhopadhyay, S.; Panda, P.K.; Sinha, N.; Das, D.N.; Bhutia, S.K. Autophagy and apoptosis: Where do they meet? Apoptosis 2014, 19, 555-566. [CrossRef] [PubMed]

150. Yao, D.; Wang, P.; Zhang, J.; Fu, L.; Ouyang, L.; Wang, J. Deconvoluting the relationships between autophagy and metastasis for potential cancer therapy. Apoptosis 2016, 21, 683-698. [CrossRef] [PubMed]

151. Lee, J.H.; Yun, C.W.; Han, Y.S.; Kim, S.; Jeong, D.; Kwon, H.Y.; Kim, H.; Baek, M.J.; Lee, S.H. Melatonin and 5-fluorouracil co-suppress colon cancer stem cells by regulating cellular prion protein-Oct4 axis. J. Pineal Res. 2018, 65, e12519. [CrossRef] [PubMed]

152. Singh, S.S.; Vats, S.; Chia, A.Y.; Tan, T.Z.; Deng, S.; Ong, M.S.; Arfuso, F.; Yap, C.T.; Goh, B.C.; Sethi, G.; et al. Dual role of autophagy in hallmarks of cancer. Oncogene 2018, 37, 1142-1158. [CrossRef] [PubMed]

153. Morel, E.; Mehrpour, M.; Botti, J.; Dupont, N.; Hamai, A.; Nascimbeni, A.C.; Codogno, P. Autophagy: A Druggable Process. Annu. Rev. Pharmacol. Toxicol. 2017, 57, 375-398. [CrossRef] [PubMed]

154. Eritja, N.; Chen, B.J.; Rodriguez-Barrueco, R.; Santacana, M.; Gatius, S.; Vidal, A.; Marti, M.D.; Ponce, J.; Bergada, L.; Yeramian, A.; et al. Autophagy orchestrates adaptive responses to targeted therapy in endometrial cancer. Autophagy 2017, 13, 608-624. [CrossRef] [PubMed]

155. Galluzzi, L.; Bravo-San Pedro, J.M.; Demaria, S.; Formenti, S.C.; Kroemer, G. Activating autophagy to potentiate immunogenic chemotherapy and radiation therapy. Nat. Rev. Clin. Oncol. 2017, 14, 247-258. [CrossRef] [PubMed]

156. Zhang, H.; McCarty, N. Tampering with cancer chemoresistance by targeting the TGM2-IL6-autophagy regulatory network. Autophagy 2017, 13, 627-628. [CrossRef] [PubMed]

157. Belounis, A.; Nyalendo, C.; Le Gall, R.; Imbriglio, T.V.; Mahma, M.; Teira, P.; Beaunoyer, M.; Cournoyer, S.; Haddad, E.; Vassal, G.; et al. Autophagy is associated with chemoresistance in neuroblastoma. BMC Cancer 2016, 16, 891. [CrossRef] [PubMed]

158. Liu, G.; Fan, X.; Tang, M.; Chen, R.; Wang, H.; Jia, R.; Zhou, X.; Jing, W.; Wang, H.; Yang, Y.; et al. Osteopontin induces autophagy to promote chemo-resistance in human hepatocellular carcinoma cells. Cancer Lett. 2016, 383, 171-182. [CrossRef] [PubMed] 
159. Jin, F.; Wang, Y.; Li, M.; Zhu, Y.; Liang, H.; Wang, C.; Wang, F.; Zhang, C.Y.; Zen, K.; Li, L. MiR-26 enhances chemosensitivity and promotes apoptosis of hepatocellular carcinoma cells through inhibiting autophagy. Cell Death Dis. 2017, 8, e2540. [CrossRef] [PubMed]

160. Xiong, L.; Liu, Z.; Ouyang, G.; Lin, L.; Huang, H.; Kang, H.; Chen, W.; Miao, X.; Wen, Y. Autophagy inhibition enhances photocytotoxicity of Photosan-II in human colorectal cancer cells. Oncotarget 2017, 8, 6419-6432. [CrossRef] [PubMed]

161. Kwitkowski, V.E.; Prowell, T.M.; Ibrahim, A.; Farrell, A.T.; Justice, R.; Mitchell, S.S.; Sridhara, R.; Pazdur, R. FDA approval summary: Temsirolimus as treatment for advanced renal cell carcinoma. Oncologist 2010, 15, 428-435. [CrossRef] [PubMed]

162. Anandappa, G.; Hollingdale, A.; Eisen, T. Everolimus-A new approach in the treatment of renal cell carcinoma. Cancer Manag. Res. 2010, 2, 61-70. [PubMed]

163. Yao, J.C.; Phan, A.T.; Jehl, V.; Shah, G.; Meric-Bernstam, F. Everolimus in advanced pancreatic neuroendocrine tumors: The clinical experience. Cancer Res. 2013, 73, 1449-1453. [CrossRef] [PubMed]

164. Dhillon, S. Everolimus in combination with exemestane: A review of its use in the treatment of patients with postmenopausal hormone receptor-positive, HER2-negative advanced breast cancer. Drugs 2013, 73, 475-485. [CrossRef] [PubMed]

165. Galluzzi, L.; Bravo-San Pedro, J.M.; Levine, B.; Green, D.R.; Kroemer, G. Pharmacological modulation of autophagy: Therapeutic potential and persisting obstacles. Nat. Rev. Drug Discov. 2017, 16, 487-511. [CrossRef] [PubMed]

166. Kumar, R.; Kapoor, A. Current management of metastatic renal cell carcinoma: Evolving new therapies. Curr. Opin. Support. Palliat. Care 2017, 11, 231-237. [CrossRef] [PubMed]

167. Njaria, P.M.; Okombo, J.; Njuguna, N.M.; Chibale, K. Chloroquine-containing compounds: A patent review (2010-2014). Expert Opin. Ther. Patents 2015, 25, 1003-1024. [CrossRef] [PubMed]

168. Redmann, M.; Benavides, G.A.; Berryhill, T.F.; Wani, W.Y.; Ouyang, X.; Johnson, M.S.; Ravi, S.; Barnes, S.; Darley-Usmar, V.M.; Zhang, J. Inhibition of autophagy with bafilomycin and chloroquine decreases mitochondrial quality and bioenergetic function in primary neurons. Redox Biol. 2017, 11, 73-81. [CrossRef] [PubMed]

169. Manic, G.; Obrist, F.; Kroemer, G.; Vitale, I.; Galluzzi, L. Chloroquine and hydroxychloroquine for cancer therapy. Mol. Cell. Oncol. 2014, 1, e29911. [CrossRef] [PubMed]

170. Lin, Y.C.; Lin, J.F.; Wen, S.I.; Yang, S.C.; Tsai, T.F.; Chen, H.E.; Chou, K.Y.; Hwang, T.I. Chloroquine and hydroxychloroquine inhibit bladder cancer cell growth by targeting basal autophagy and enhancing apoptosis. Kaohsiung J. Med. Sci. 2017, 33, 215-223. [CrossRef] [PubMed]

171. Frieboes, H.B.; Huang, J.S.; Yin, W.C.; McNally, L.R. Chloroquine-mediated cell death in metastatic pancreatic adenocarcinoma through inhibition of autophagy. J. Pancreas 2014, 15, 189-197.

172. Zhao, X.G.; Sun, R.J.; Yang, X.Y.; Liu, D.Y.; Lei, D.P.; Jin, T.; Pan, X.L. Chloroquine-enhanced efficacy of cisplatin in the treatment of hypopharyngeal carcinoma in xenograft mice. PLoS ONE 2015, 10, e0126147. [CrossRef] [PubMed]

173. Liang, D.H.; El-Zein, R.; Dave, B. Autophagy Inhibition to Increase Radiosensitization in Breast Cancer. J. Nuclear Med. Radiat. Ther. 2015, 6, 254. [CrossRef] [PubMed]

174. Rangwala, R.; Chang, Y.C.; Hu, J.; Algazy, K.M.; Evans, T.L.; Fecher, L.A.; Schuchter, L.M.; Torigian, D.A.; Panosian, J.T.; Troxel, A.B.; et al. Combined MTOR and autophagy inhibition: Phase I trial of hydroxychloroquine and temsirolimus in patients with advanced solid tumors and melanoma. Autophagy 2014, 10, 1391-1402. [CrossRef] [PubMed]

175. Barnard, R.A.; Wittenburg, L.A.; Amaravadi, R.K.; Gustafson, D.L.; Thorburn, A.; Thamm, D.H. Phase I clinical trial and pharmacodynamic evaluation of combination hydroxychloroquine and doxorubicin treatment in pet dogs treated for spontaneously occurring lymphoma. Autophagy 2014, 10, 1415-1425. [CrossRef] [PubMed]

176. Rosenfeld, M.R.; Ye, X.; Supko, J.G.; Desideri, S.; Grossman, S.A.; Brem, S.; Mikkelson, T.; Wang, D.; Chang, Y.C.; Hu, J.; et al. A phase I/II trial of hydroxychloroquine in conjunction with radiation therapy and concurrent and adjuvant temozolomide in patients with newly diagnosed glioblastoma multiforme. Autophagy 2014, 10, 1359-1368. [CrossRef] [PubMed] 
177. Liu, J.; Xia, H.; Kim, M.; Xu, L.; Li, Y.; Zhang, L.; Cai, Y.; Norberg, H.V.; Zhang, T.; Furuya, T.; et al. Beclin1 controls the levels of p53 by regulating the deubiquitination activity of USP10 and USP13. Cell 2011, 147, 223-234. [CrossRef] [PubMed]

178. Shao, S.; Li, S.; Qin, Y.; Wang, X.; Yang, Y.; Bai, H.; Zhou, L.; Zhao, C.; Wang, C. Spautin-1, a novel autophagy inhibitor, enhances imatinib-induced apoptosis in chronic myeloid leukemia. Int. J. Oncol. 2014, 44, 1661-1668. [CrossRef] [PubMed]

179. Ronan, B.; Flamand, O.; Vescovi, L.; Dureuil, C.; Durand, L.; Fassy, F.; Bachelot, M.F.; Lamberton, A.; Mathieu, M.; Bertrand, T.; et al. A highly potent and selective Vps34 inhibitor alters vesicle trafficking and autophagy. Nat. Chem. Biol. 2014, 10, 1013-1019. [CrossRef] [PubMed]

180. Pasquier, B. SAR405, a PIK3C3/Vps34 inhibitor that prevents autophagy and synergizes with MTOR inhibition in tumor cells. Autophagy 2015, 11, 725-726. [CrossRef] [PubMed]

181. Chen, S.; Wang, C.; Yeo, S.; Liang, C.C.; Okamoto, T.; Sun, S.; Wen, J.; Guan, J.L. Distinct roles of autophagy-dependent and -independent functions of FIP200 revealed by generation and analysis of a mutant knock-in mouse model. Genes Dev. 2016, 30, 856-869. [CrossRef] [PubMed]

182. Vega-Rubin-de-Celis, S.; Zou, Z.; Fernandez, A.F.; Ci, B.; Kim, M.; Xiao, G.; Xie, Y.; Levine, B. Increased autophagy blocks HER2-mediated breast tumorigenesis. Proc. Natl. Acad. Sci. USA 2018, 115, 4176-4181. [CrossRef] [PubMed]

(C) 2018 by the authors. Licensee MDPI, Basel, Switzerland. This article is an open access article distributed under the terms and conditions of the Creative Commons Attribution (CC BY) license (http://creativecommons.org/licenses/by/4.0/). 